\title{
Water content, pH and cooking loss of broiler meat with garlic-based herbs solution on drinking water
}

\author{
Tati Vidiana Sari $^{1 *}$, Putri Zalukhu ${ }^{2}$, and $R$ Edhy Mirwandhono ${ }^{1}$ \\ ${ }^{1}$ Lecturer of Animal Husbandry Department, Faculty of Agriculture, Universitas Sumatera Utara, \\ Medan-20155, Sumatera Utara, Indonesia \\ 2 Student of Animal Husbandry Department, Faculty of Agriculture, Universitas Sumatera Utara, \\ Medan-20155, Sumatera Utara, Indonesia
}

\begin{abstract}
The purpose of this study was to determine the effect of garlicbased herbs (combinatioan with shallot, Kaempferia galanga, ginger, betel leaf, turmeric, Curcuma zanthorrhiza, Alpinia galanga, lemongrass and coriander) solution as drinking water during broiler raising on the water content, $\mathrm{pH}$ and cooking loos value of the broiler meat. The research design used a CRD with 7 treatments and 3 replications. The dose of herbs ingredients used $25 \%$ of the daily drinking water requirement. The results showed a very siginificant difference $(\mathrm{P}<0.01)$ to water content and cooking loss but were not significant difference $(\mathrm{P}>0.05)$ to the $\mathrm{pH}$ value. The results of DMRT showed that the water content of broiler meat with treatment $\mathrm{K} 2, \mathrm{~K} 5$, and $\mathrm{K} 5$ was significantly higher than $\mathrm{K} 0, \mathrm{~K} 1, \mathrm{~K} 4$ and $\mathrm{K} 3$ while the cooking loss value showed that the treatment at $\mathrm{K} 0$ and $\mathrm{K} 6$ was significantly higher than $\mathrm{K} 2, \mathrm{~K} 4, \mathrm{~K} 5$ and $\mathrm{K} 1$. It can be concluded that the giving of drinking water with garlic and Kaempferia galanga solution produces the lowest of water content $(66,89 \%), \mathrm{pH}(6,61)$ and cooking loss $(32,23 \%)$ values, so it can be used as an additive in animal feed with to improving the quality of broiler meat.
\end{abstract}

\section{Introduction}

Meat has a complete and balanced nutritional content to human nutritional needs, including broiler meat. The nutritional of broiler meat consist of $18,5 \%$ protein, $15,06 \%$ fat, $65,95 \%$ water content and $0,79 \%$ ash [1]. The high content causes meat to be a good medium for microbial growth, so meat is also categorized as one of the perishable food products of animal origin besides milk. One of the causes of physical damage to meat is the activity of microorganisms that can come from infection from live broiler or postmortem contamination of meat. One form of contamination of the meat surface that can occur from

*Corresponding author: tati.vidiana@usu.ac.id 
the time when the poultry are slaughtered until it is consumed [2] which is indicated by changes in smell, taste and the presence of mucus.

One of the factors that influence the growth of microbial in meat is intrinsic factors including the nutritional value of meat, water content, $\mathrm{pH}$, oxidation-reduction potential and the presence or absence of inhibitory substance. Water and oxygen are one of the basic needs for microorganisms to breed in addition to nitrogen derived from protein in meat [2]. The water content available in the meat will determine the growth rate of microorganisms. The high water content in the meat will result in the potential for damage to the meat during storage is also very large. In addition to water content, the $\mathrm{pH}$ level of the meat also determines the quality of broiler meat. The $\mathrm{pH}$ level of meat under normal conditions is around 5,3-5,7 and most bacteria will grow well at a $\mathrm{pH}$ of 7,0 [2]. Normal $\mathrm{pH}$ levels can reduce the potential for postmortem meat damage.

Other meat quality can also be determined from the cooking loss value. Cooking loss value can be influenced by $\mathrm{pH}$, type of livestock and weight of meat sample when cooked [2]. The amount of cooking loss can describe the potential for loss of nutritional value of meat during the cooking process. The low cooking loss value of broiler meat can indicate good meat quality, so to maintain the quality of the meat, various preservation efforts are carried out.

Herbs or medicinal plants in Indonesia such as shallot, ginger, garlic, curcuma or turmeric have often been used in the meat preservation process such as marinating, but the use of these plants is through drinking water given during maintenance starting from rearing of broiler until before the harvest has been done much. Medicinal plants used as herb ingredients in livestock are referred to as phytobiotics [3]. Several types of herbs have been reported as herbal drinks with single use or a combination of several ingredients $[4,5$ and 6]. Garlic also contains flavonoid and essentials oil, which also has antibacterial activity [7] and garlic extracts showed a powerful inhibitory effect against pathogens compared with Ampicillin as antibiotic [8].

Herb ingredients tend to improve livestock performance, but their directs effects on postmortem meat quality such as water content, $\mathrm{pH}$ and cooking loos have not been widely reported. One of the advantages in the use of herbs plants in livestock raising is thought to be able to replace the use of antibiotic growth promoters that are often used by farmers in animal husbandry. These antibiotic residues can pollute the environtment around the farm so that a lot of herbs ingredients are needed to replace the use of antibiotics in the farms so that they can create a healthy and sustainable environment for every living thing.

\section{Materials and methods}

\subsection{Time and Research Place}

This research was conducted from July to August 2021 at the Farm House in Kapten Muslim Street of Medan City and Laboratory of Food Biochemistry in Faculty of Mathematics and Natural Sciences, Universitas Sumatera Utara.

\subsection{Materials and tools}

The material used is meat from broiler chickens harvested at the 35 days old, commercial feed, drinking water with herbs solution according to treatment. The tool use are food container, refrigerator, drink holder, harvesting equipment, digital scace, knife, plastic wrap, dan cutting board. The total number of samples are 21 with 2 replications each of broiler meat. 


\subsection{Research methods}

This research used was an experimental design were analyzed by the procedure performs analysis of variance with CRD ( 7 treatmens and 3 replications). Duncan's test was used for multiple comparisons to identify significant differences between means $(\mathrm{P}, 0.05)$.

\subsection{Research parameters}

Test parameters and methods are as follows:

\subsubsection{Water content of meat}

The water content can be calculated using the method of Air-oven drying that is very convenient, and is one of the most widely and commonly used methods for routine water determination in laboratories around the world $[9,10]$ or using the mouisturemeter.

\subsection{2 $\mathrm{pH}$ of meat}

Meat $\mathrm{pH}$ is the level or degree of acidity of meat after postmortem. The principle of measuring $\mathrm{pH}$ is knowing the acidic and basic conditions. The tip of the $\mathrm{pH}$ meter is inserted into a $10 \mathrm{~g}$ of broiler meat sample. Meat $\mathrm{pH}$ measurement can use a $\mathrm{pH}$ meter [11].

\subsubsection{Cooking loss}

Cooking loss was calculated using the method [12]. Meat samples from harvested broilers were taken from the boneless breast immediately after slaughter and then weighed $10 \mathrm{~g}$ and put in a plastic bag and in vacuum. Then the meat is brought to the laboratory to calculate the cooking loss value. The average weight of a breast fillet is $10 \mathrm{~g}$. The fillet samples were boiled to an temperature of $60^{\circ} \mathrm{C}$ for 1 hour. Samples were removed from the boil pot and cooled down using 5 and 10 minute for estimating cook loss. A total of 21 single fillets were used in this experiment and the entire experiment was repeated twice at same time. The cook loss were calculating using following formula : \% cook loss $=\left(\mathrm{W}_{1}-\mathrm{W}_{2}\right) / \mathrm{W}_{2} \mathrm{x}$ 100 , where $\mathrm{W}_{1}$ is weight of raw meat samples before cooking and $\mathrm{W}_{2}$ is the postcook weight of the samples cooled at the room temperature.

\subsection{How to make herbs drinks}

The herbs solution used are garlic, shallot, Kaempferia galanga, ginger, betel leaf, turmeric, Curcuma zanthorrhiza, Alpinia galanga, lemonggrass and coriander. The dose of herbs ingredients used in each treatment is $125 \mathrm{~g} / \mathrm{L}$ water. The material to used according to the teratment was weighed as much as $125 \mathrm{~g} / \mathrm{L}$ of water to be used to boil the herbs. Then the herbs is trimmed, blended and boiled to an endpoint temperature of $95^{\circ} \mathrm{C}$. The boiled herbs solution is filtered and stored. It can be stored at room temperature for up to 2 days and 5 days at refrigerator temperature. These herbs solution can be used as much as $25 \%$ of the daily drinking water requirement of broilers for 4 weeks.

\section{Results and discussion}

The use of various types of herbs that exist in Indonesia to improve the quality of broiler meat can be done through the provision of herbs boiled water into a drink for broilers 
during the rearing process. The treatment given was drinking water with the addition of : K0 (without additional herbs drinks); K1 (garlic); K2 (garlic with shallot); K3 (garlic with Kaempferia galanga); K4 (garlic with ginger); K5 (garlic with shallot, Kaempferia galanga, Curcuma zanthorrhiza and betel leaf); and K6 (garlic with shallot, Kaempferia galanga, Curcuma zanthorrhiza, betel leaf, Alpinia galanga, lemongrass and coriander). The following are the results of this research using a mixture of various types of herbs on mousiture content, $\mathrm{pH}$ and cooking loss of broiler meat after harvesting at the age of 35 days in Table 1.

\subsection{Water content of broiler breast}

Water content of broiler breast in this research presented in Table 1. Based on the ANOVA, it showed that the giving of garlic-based herbs solution had a very significant difference $(\mathrm{P}<0.01)$ on the water content. The average value of the water content $(\%)$ in this reasearch were respectively $73.61 \%(\mathrm{~K} 0), 71.56 \%(\mathrm{~K} 1), 74.46 \%(\mathrm{~K} 2), 66.89 \%(\mathrm{~K} 3), 71,10 \%(\mathrm{~K} 4)$, $76,59 \%$ (K5) and 76,07\% (K6). The value of water content range from $66.89-76.59 \%$ with an average of $72.89 \%$ and this figure is still included in normal water content of chicken meat, namely $65-80 \%$ [13].

Table 1. The effect of garlic-based herbs solution on broiler meat quality

\begin{tabular}{|c|c|c|c|}
\hline \multirow{2}{*}{ Treatment } & \multicolumn{3}{|c|}{ Average Value of } \\
\cline { 2 - 4 } & $\begin{array}{c}\text { Mouisture Content } \\
(\%)\end{array}$ & $\mathbf{p H}$ & Cooking Loss (\%) \\
\hline K0 & $73.61 \pm 15.17^{\mathrm{B}}$ & $6.70 \pm 0.029^{\mathrm{ns}}$ & $39.37 \pm 1.60^{\mathrm{A}}$ \\
\hline $\mathrm{K} 1$ & $71.56 \pm 12.54^{\mathrm{B}}$ & $6.73 \pm 0.024^{\mathrm{ns}}$ & $32.83 \pm 10.17^{\mathrm{C}}$ \\
\hline $\mathrm{K} 2$ & $74.46 \pm 1.60^{\mathrm{A}}$ & $6.68 \pm 0.011^{\mathrm{ns}}$ & $36.80 \pm 3.16^{\mathrm{B}}$ \\
\hline $\mathrm{K} 3$ & $66.89 \pm 3.91^{\mathrm{C}}$ & $6.61 \pm 0.015^{\mathrm{ns}}$ & $32.23 \pm 3.16^{\mathrm{C}}$ \\
$\mathrm{K} 4$ & $71.10 \pm 1.28^{\mathrm{B}}$ & $6.62 \pm 0.008^{\mathrm{ns}}$ & $36.33 \pm 1.10^{\mathrm{B}}$ \\
K5 & $76.59 \pm 1.43^{\mathrm{A}}$ & $6.99 \pm 0.089^{\mathrm{ns}}$ & $36.77 \pm 3.80^{\mathrm{B}}$ \\
$\mathrm{K} 6$ & $76.07 \pm 5.01^{\mathrm{A}}$ & $6.77 \pm 0.002^{\mathrm{ns}}$ & $39.13 \pm 0.16^{\mathrm{A}}$ \\
\hline
\end{tabular}

Note: $\mathrm{ns}=$ Non significant difference $(\mathrm{P}>0.05)$

A, B, C, D = Different letter notations on the same column show that high significantly different at the $1 \%$ level according to the DMRT test

Duncan's test results show that the water content of broiler breast on K2, K5 and K6 was very significant difference $(\mathrm{P}<0.01)$ compared with $\mathrm{K} 0, \mathrm{~K} 1, \mathrm{~K} 4$ and the value on $\mathrm{K} 3$ is very significant difference lower than the others. $\mathrm{K} 3$ is a solution with garlic and Kaempferia galanga. The active compounds that can be extracted from garlic are allicin, allyl and diallyl sulfide, which can inhibit the growth of several types of microbes. Garlic's high antimicrobial activity is due to the allicin and diallyl sulfide content contained in garlic essential oil showing inhibitory activity for bacterial growth [14]. With the presence of allicin, bacterial growth can be inhibited and has a positif effect on livestock growth [15] including lowering the water content in the meat that has been properly metabolized by the broiler's body. The active substance in Kaempferia galanga are saponins and flavonoids that can help the performance of bile and act as antibiotic [16,17]. The essential oil of Kaempferia galanga is $3.35 \%$ and the curcumin content is $0.006 \%$ [18].

The use of herbs solution containing only garlic (K1) and garlic with ginger (K4) had the same water content value as without giving herb solution. This is presumably because the active substances in garlic have not been optimally utilized by broiler's metbolism as 
well as a solution from garlic with ginger, so that the results of the water content of the broiler breast are still the same $(\mathrm{P}>0.05)$. High water content in meat causes meat to rot quickly after postmortem due to fast microbial growth in meat that has a moisture content above $80 \%$ [2].

\section{$3.2 \mathrm{pH}$ value of broiler breast}

The $\mathrm{pH}$ value of broiler breast on this study presented in Table 1 . The average $\mathrm{pH}$ value obtained from the treatment were respectively $6.70(\mathrm{~K} 0), 6.73(\mathrm{~K} 1), 6.68(\mathrm{~K} 2), 6.61(\mathrm{~K} 3)$, $6,62(\mathrm{~K} 4), 6,99(\mathrm{~K} 5)$ and $6.77(\mathrm{~K} 6)$. The $\mathrm{pH}$ value is one of the criteria for the physical characteristics of meat and $\mathrm{pH}$ will be decrease at postmortem. $\mathrm{pH}$ value can used to indicate the level of acidity and alkalinity of a meat whose value when the animal are still alive is around 7.0-7.2. After postmortem, $\mathrm{pH}$ value in the muscles will decrease due to the accumulation of lactic acid. Decrease in the $\mathrm{pH}$ value of animal muscles properly handled prior to postmortem will progress gradually from 7.0 to 5.6-5.7 within 6-8 hours postmortem and will reach a final $\mathrm{pH}$ value of about 5.5-5.6 [19] and the $\mathrm{pH}$ of the broiler breast in this research is still within the normal $\mathrm{pH}$ range of meat in postmortem conditions.

The results of the ANOVA showed that the giving of garlic-based herbs solution were not significant difference $(\mathrm{P}>0.05)$ on $\mathrm{pH}$ Value. The $\mathrm{pH}$ value of the meat will be determined by the amount of lactate produced from glycogen during the process of anaerobic glycolisis and this will limited when glycogen is depleted due to fatigue, hunger or fear of animals before cutting [20]. The $\mathrm{pH}$ value of meat never reach a value below 5.3. This is due to enzymes that involved in inactive anaerobic glycolysis work [21] This is in accordance with the data research in Table 1. It is known that the $\mathrm{pH}$ value of broiler breast with the giving of garlic-based herbs solution does not under 5.3. The active substances in all garlic-based herbs solution giving can be metabolized by broiler body properly, so that the $\mathrm{pH}$ value of this meat is in normal conditions in all treatments.

\subsection{Cooking loss of broiler breast}

Cooking loss is an indicator of value meat nutrition related to levels of meat juice is the amount of water bound in and between muscle fibers. Meat juice is components of meat determine tenderness of meat [2]. The average of cooking loss (\%) obtained from this research were respectively 39.37 (K0), 32.83 (K1), 36.80 (K2), 32.23 (K3), 36.33 (K4), 36.77 (K5) and 39.13 (K6).

The results of the analysis showed that giving of garlic-based herbs solution had a very significant difference $(\mathrm{P}<0.01)$ in reducing the cooking loss value of broiler breast. The value of cooking loss was between 32.23-39.37\% (Table 1). This value including normal. This is in accordance with the opinion of Soeparno [2], that in general the value of cooking loss value of meat varies between $1.5-54.5 \%$ with a range of $15-40 \%$. The magnitude of the value of the cooking loss of meat is very influenced by the $\mathrm{pH}$ value of the meat, when the $\mathrm{pH}$ value is higher or lower than isoelectric point (5.0-5.1), the the value of cooking loss of the meat will be low. The content of low cooking loss will make quality meat is good and the meet have a low cooking loss value below $35 \%$ has good quality because possible release of meat nutrients during cooking is also low [22]. According to this statement, the data of this research showed that the good quality broiler meat was present in the treatment of K1 (garlic solution herbs drink) and K3 (garlic with Kaempferia galanga solution herbs drink), because it has a cooking loss value below $35 \%$. 
Duncan's test result show that the cooking loss of broiler breast on K0 and K6 was very significant difference $(\mathrm{P}<0.01)$ higher than $\mathrm{K} 2, \mathrm{~K} 4$ and $\mathrm{K} 5$ and the value on $\mathrm{K} 1$ and $\mathrm{K} 3$ is very significant difference lower than the others. $\mathrm{K} 1$ is a broiler breast with giving garlic solution and K3 with garlic and Kaempferia galanga. Factors that cause differences cooking loss values include the type of animal, cutting method, latitude type, fat content, $\mathrm{pH}$ value, muscle fiber sarcomere length, myofibril contraction status, size and sample weight, cross-section of meat, warming, meat fat, age and energy consumptioan in feed [23]. The material active of medicinal plants are able to inhibit growth (inhibitory activity) against food borne pathogens, fungi, and pathogens in the digestive tract [24], increase the digestibility ob substances food [25], so this affects the quality of the meat during broiler growth.

\section{Conclusion}

The conclusion of this study is the giving of garlic based herbs solution on broiler drinking water showed a very siginificant difference $(\mathrm{P}<0.01)$ to water content and cooking loss but gave results that were not significant difference $(\mathrm{P}>0.05)$ to the $\mathrm{pH}$ value of broiler meat. The results of the Duncan's test showed that the water content of broiler meat with treatment $\mathrm{K} 2, \mathrm{~K} 5$, and $\mathrm{K} 5$ was significantly higher than $\mathrm{K} 0, \mathrm{~K} 1, \mathrm{~K} 4$ and $\mathrm{K} 3$ while the cooking loss value showed that the treatment at K0 and $\mathrm{K} 6$ was significantly higher than $\mathrm{K} 2, \mathrm{~K} 4, \mathrm{~K} 5$ and $\mathrm{K} 1$. It can be suggested that the giving of drinking water with garlic and Kaempferia galanga (K3) solution produces the lowest of water content $(66,89 \%)$, $\mathrm{pH}$ $(6,61)$ and the lowest of cooking loss $(32,23 \%)$ so that it can be used as an additive in animal feed with to improving the quality of broiler meat.

\section{References}

1. W.J. Stadelman, V.M Olson, G.A Shmwell, S. Pasch, Egg and Poultry Meat Processing (Ellis Harwood Ltd, London, 1988)

2. Soeparno, Ilmu dan Teknologi Daging 4th ed (Gajah Mada University Press, Yogyakarta, 2009)

3. L.W. Hidayat, Pengaruh penambahan fitobiotik, acidifier, dan probiotik, bentuk non emkskapsulasi enkapsulasi dalam adiktif pakan terhadap karakteristik usus itik pedaging (Sarjana Thesis Universitas Brawijaya, Malang, 2015)

4. M. Ulfah, Media Konservasi XI 3 pp 109-114 (2006)

5. D.L. Yulianti, H. Leondro, Y.P. Mole, J. Agrisains 152 pp 1-13 (2014)

6. M. M. D. Utami, D. Pantaya, Penggunaan Ekstrak Bawang Putih dalam Pakan terhadap Performans Ayam Broiler Tropis Fase Starter pada Prosiding Seminar Hasil Penelitian dan Pengabdian Masyarakat Tahun 2016 pp 72-75 (2016)

7. J. Salima, Med. J. of Lampung University 42 pp 30-39 (2015)

8. R. M. Ismail, A. H. A. Saleh, K. S. Ali, J of Medicinal Plants Studies 81 pp 26-30 (2020)

9. Y. Pomeranz, C. E. Meloan, Determination of water In Food Analysis: Theory and Practice 3rd ed (Chapman and Hall, New York, 1994)

10. A. Pande, Handbook of Water Determination and Control Vol. 1 (Marcel Dekker, New york, 1974)

11. J. D. Merthayasa, I. K. Suada, K. K. Agustina, Indonesia Medicus Veterinus 41 (7) pp 16-24 (2015) 
12. B. Pang, B. Bowker, H. Zhuang, J. Y. Y. Zhang, Poultry Science 99 pp 6287-6290 (2020)

13. J. C. Forrest, E. D. Aberle, H. B. Hedrick, M. D. Judge, R. A. Markell, Principle of Meat Sience (W. H. Freman and Co., San Fransisco, 1975)

14. E. Block, A. Saleem, J. L. Catalfamo, M. K. Jain, R. A. Castro, J. Am. Chem. Soc. 108 (22) pp 7045-7055 (1986)

15. C. Santosa, Pembibitan Tanaman Obat (Penebar Swadaya, Jakarta, 1991)

16. T. Robinson, The Organic Constituents of Higher Plants (ITB Press, Bandung, 1995)

17. R. D. Wirapati, Efektivitas pemberian tepung kencur (Kaempferia galanga L.) pada ransum ayam broiler rendah energi dan protein terhadap performan ayam broiler, kadar kolestrol, persentase hati dan bursa fabrisius (Laporan Penelitian Institut Pertanian Bogor, Bogor, 2008)

18. L. Agustina, Penggunaan ramuan herbal sebagai feed additive untuk meningkatkan performans broiler pada Prosiding Lokakarya Nasional Inovasi Teknologi dalam Mendukung Usaha Ternak Unggas Berdaya Saing Pusat Penelitian dan Pengembangan Peternakan pp 47-52 (2006)

19. D. Septinova, Riyanti, V. Wanniatie, Dasar Teknologi Hasil Ternak (Universitas Lampung, Lampung, 2016)

20. K. A. Buckle, R. A Edwards, G. H. Fleet, M. Wootton, Food Science (UI Press, Jakarta, 1987)

21. D. W. Lukman, Nilai pH Daging (Departemen Kesehatan Masyarakat Veteriner FKH IPB, Bogor, 2010)

22. H. Yanti, Hidayati, Elfawati, J. Peternakan 51 pp 22-27 (2008)

23. Nurwanto, Septianingrum, Surhatayi, Buku Ajar Dasar Teknologi Hasil Ternak (Universitas Diponegoro, Semarang, 2003)

24. I. A. K. Bintang, A. G. Nataamijaya, Pengaruh penambahan tepung kencur (Kaempferia galanga L) dan tepung bawang putih (Allium sativum L) ke dalam pakan terhadap performan broilers (Laporan Penelitian Balai Penelitian Ternak, Bogor, 2004)

25. M. Ulfah, Influence of essential oils on the performance data and health condition of monogastric animals (Thesis Agricultural Faculty, George August University Göttingen, Germany, 2003) 